UDC 339.138

JEL Classification: M31, M39

http://doi.org/10.21272/mmi.2019.2-08

Fue Zeng,

Wuhan University, China

Muhammad Yaseen Bhutto,

Wuhan University, China

Yasir Ali Soomro,

King Abdulaziz University, Saudi Arabia

\title{
CHINESE SMARTPHONE BRANDS: GENDER, CONSUMERS BEHAVIOURAL AND ATTITUDINAL LOYALTY
}

Abstract. This study investigates the relationship between brand image, brand awareness, brand satisfaction, brand trust, attitudinal, and behavioural loyalty of domestic Chinese Smartphone brands among young consumers and determines the mediating effects of brand trust. This study also investigates gender differences. Only a few studies in previous literature related to Chinese Smartphone brands and their loyalty towards their domestic brands, therefore this study contributes to the literature. Survey questionnaires were collected from 188 full-time young students in a public university in Wuhan, China. The Partial Least Squares Structural Equation Modelling was employed in the data analysis. The findings revealed significant relationships between brand image and brand trust, brand satisfaction, and brand trust, brand trust, and (attitudinal \& behavioural loyalty) except for brand awareness. Also, brand trust found to mediate the relationship between brand image and (attitudinal \& behavioural loyalty) and brand satisfaction and (attitudinal \& behavioural loyalty), but our finding suggests that brand trust failed to mediate in the relationship between brand awareness and (attitudinal and behavioural loyalty). The findings revealed that impact of brand awareness on brand trust found to be insignificant in both gender (male \& female), impact of brand Image found to be significant in male but insignificant in female group. Impact of brand satisfaction on brand trust found to be significant in both genders, but impact is higher in male than female gender. Also, the study found that male user is more concerned about behavioural loyalty while female more concerned about attitudinal loyalty. This study suggests that domestic brands are lacking in creating awareness, so domestic brands need to focus on their marketing strategies and advertisements plans and also makes the strategies that can attract both male and female gender and entertain their concerns as well. This study further suggests that marketers and managers of domestic brands keep their eye open on international competing brands and modified their strategies to achieve effectiveness and efficiency so that local brands can have sustainable growth and competitive edge in the industry.

Keywords: brand image, brand satisfaction, brand awareness, brand trust, attitudinal loyalty, behavioural loyalty, gender.

Introduction. The brand is considering vital and most priceless assets for any national and multinational business organization. Brand has extensively acknowledged as an essential cause for consumer preference which serves as a mechanism for consumers to ensure the differentiation of the products and their rareness whereby it also enhances consumers' confidence and trust (Florence and Catherine, 2012). A smartphone is one of the most ubiquitous brands (Bai, Wang and Zeng, 2018; Guo and Yan, 2017; Ongondo and Williams, 2011). The figure for worldwide mobile phone subscribers has reached 7.1 billion («ITU Annual Reports», 2015). This proliferation is due to the swift development of network infrastructure and the increasing fame of Smartphone, a mobile phone is not only used for communication, but it has gradually become part of every aspect of our lives (Bai et al., 2018). Since 2004, China has become the world's leading manufacturer and consumer of mobile phones, and the industry has been growing ever since. According to a report of MIIT (2016) «In China, the number of smartphones manufactured from the period of January to November 2016 was 1.4 billion, accounting for $70.4 \%$ of the whole volume of mobile phones manufactured during that period, with $12.7 \%$ raise from that in 2015» («MIIT Report», 2016).

Cite as: Zeng, F., Bhutto, M. Y., \& Soomro, Y. A. (2019). Chinese Smartphone Brands: Gender, Consumers Behavioural and Attitudinal Loyalty. Marketing and Management of Innovations, 2, 83-98. http://doi.org/10.21272/mmi.2019.2-08 

Loyalty

Smartphone now accounts for more than half of the market share of mobile phones, and the trend is rising. Nowadays, there is hard competition in business environments, and it also exists in the smartphone industry as well. However, because of attributes similarities, it is challenging for the consumer to distinguish the product or brand on the bases of technology development, brand performance, and resources development. When products and brands are more similar, competitive in price; therefore, consumer retention is vulnerable to switch towards another brand or product (Chien, Chang and Su, 2003). However, number of similar brands that provide the same purpose, it makes consumers more awake and offers more advantages or benefits cause them to change their brand easily (Wood, 2006), this situation also occurs in the smartphone industry. Due to these reasons, it is tough for companies to retain existing customers because loyal customers will recommend their brand to their friends, peer groups, and also spread positive word of mouth. As a result, the firm will able to achieve and improve its market share at little cost (Lau and Lee, 1999; Zuhroh, 2014). Companies used to develop new strategies and values to keep consumers connected to their brand and remain loyal, as brand loyalty has some marketing benefits, as it lowers marketing costs and attract more new and fresh customers (Algesheimer et al., 2005).

Furthermore, brand loyalty also creates an increase in a firm's competitiveness and success (Chaudhuri and Holbrook, 2001). Brand loyalty usually occurs when a consumer believes that a certain product/service is the finest among the alternative brands regarding quality, performance, price and therefore, frequently purchases it or refers others to it (Fullerton, 2005). The cross-examination of the accessible marketing literature shows that brand loyalty was considered one of the most fundamental drivers of the company, which is responsible for the company profitability (Reichheld, Markey $\mathrm{Jr}$ and Hopton, 2000). Brand loyalty has been considered most discussed and not properly understood the concept of marketing (Kabiraj and Joghee, 2011). Firms want their consumers to be attached to their brands and remain loyal,but several factors influence loyalty it includes brand image, brand awareness, brand satisfaction, brand trust all these factors are beneficial to understand the construct of the brand loyalty (Ercis et al., 2012; Kara et al., 2013).

To date, earlier studies on brands by (Kara et al., 2013; Fleck, Korchia and Le Roy, 2012; Thwaites et al., 2012) were conducted in non-Asian countries, with expected results less comparable to Asian countries such as China. Further, less concentration focuses on understanding factors such as brand image, brand awareness, brand trust, and satisfaction that influence the behavioural and attitudinal loyalty in China, especially among young consumers. Additionally, increasing number of empirical studies on brand loyalty to global and international brands (Nezakati, 2011; Sze, 2012), to the knowledge of the researchers, few studies have been carried out to investigate consumer brand loyalty to local brands (Schuiling and Kapferer, 2004; Zhang and Schmitt, 2001).

This study fills the gap by investigating the essential factors purported to enhance brand loyalty. Previous research indicates that price, product or brand characteristics and features influence consumer's behaviour such as purchase intention (Tsai and Ho, 2013) fewer studies entertain the subjective perspective such as brand image, awareness, trust, behavioural \& attitudinal loyalty especially in the context of domestic brands. This study investigates the impact of brand image, brand awareness, and brand satisfaction on attitudinal and behavioural loyalty of young Chinese consumers towards domestic Smartphone brands. Second, considering trust, consumers always rely on trusted brands to save time and other search costs. Also, it allows the consumer's trust to build a personal relationship with the brand (Hess and Story, 2005). Brand trust leads to brand loyalty because trust creates an exchange that is highly valued and influences consumer behaviour in relationship marketing (Morgan and Hunt, 1994b). Therefore it assumed that a brand that demonstrates better image, satisfaction, and awareness will ensure consumers' willingness to maintain the relationship and future purchases. 

Loyalty

Based on this logic, this study suggests the mediate effect of brand trust because of lack of studies on the mediating effects of brand trust especially in the context of local brands (Al-Hawary, 2013; Akdeniz and Kara, 2014). Thirdly this study investigates the moderating role of gender in the relationship between brand image, brand awareness, brand satisfaction, brand trust, and behavioural \& attitudinal loyalty; gender has been less investigated particularly in the scenario of emerging markets (Jaiswal and Kant, 2018; Lee, 2009) (figure 1).

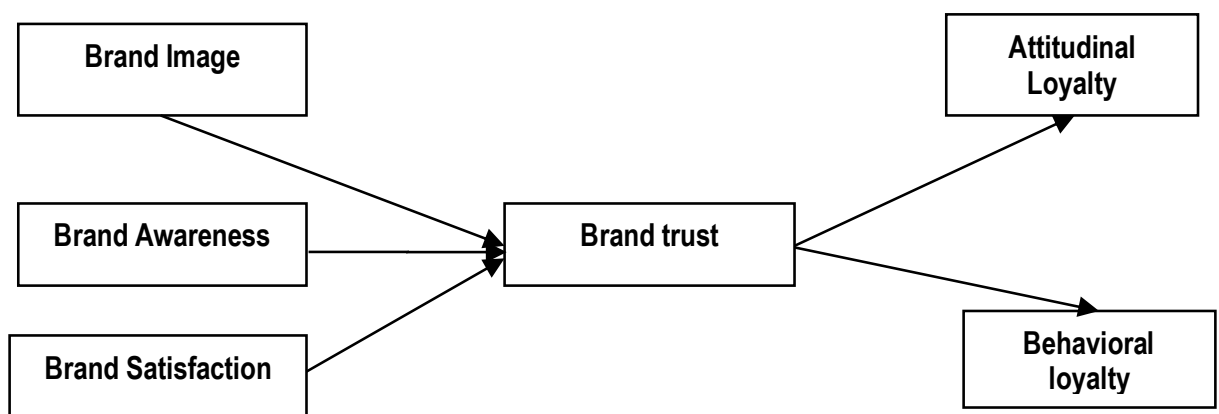

Figure 1. Proposed conceptual model for Brand Loyalty

Literature Review. The relationship between brand image and brand trust has been considered very important by researchers in various fields. Alhaddad (2015), examines the relationship between brand image and brand trust among students using the model of the structural equation. The results of the study showed that the brand image significantly influences the brand trust of the students. Also, past researchers have indicated a brand image has a constructive and significant influence on brand trust (Chen, 2010; Esch et al., 2006). When consumers have strong trust in the brand, they expect a good brand image (Sean Hyun and Kim, 2011). Hence, it posited that higher the brand image, the higher the estimated brand trust that consumer would conceptualize. Previous empirical evidence has shown that the brand image will boost consumer confidence in a brand's end, and thus lead to brand trust (Richard, 2016; Rio, Rodolfo and Victor, 2001). It is, therefore, to be expected that the brand image will lead to brand trust in the context of domestic Smartphone brands.

H1: For domestic Smartphone brand, brand image has a direct positive impact on brand trust.

Brand awareness is crucial for the consumer because brands are more familiar and known have more chances to be selected by consumers than to unknown brands (Panchal, Khan and Ramesh, 2012). According to (Yoo and Donthu, 2002), recommended that brand awareness is significantly related to brand trust, some scholars believed that brand trust is a psychological state of confidence and positive expectations belong from a brand, and it also decreases the level of consumer's uncertainties and risk. Brand awareness reduces the risk of errors in purchasing product because brand ensures the quality of the product. According to consumer context that consumers do not need to think a lot and gather information about the quality of the product if the consumer already trusts the brand. From the support of the above explanation, it can be concluded that brand awareness has a positive and significant effect on brand trust $(\mathrm{Ha}, 2004)$. Therefore, growing brand awareness about domestic brands is expected to increase consumer trust in domestic brands.

$\mathrm{H} 2$ : For domestic Smartphone brand, brand awareness has a direct positive impact on brand trust.

Researchers signify that it is essential to be aware of the satisfaction along with trust to predict the loyalty (Schultz, Block and Viswanathan, 2014). Trust is a commitment in general and is mostly making unique associations with brands (Jeff and John, 2005). Trust is considered very important to develop a 
consumer-brand relationship (Sahin, Zehir and KitapcI, 2011). Consumers build up their trust in the brand based on expectations, positive belief, performance, and satisfaction of products a brand represents (Ashley and Leonard, 2009). Yoo and Donthu (2002) in his research examined the correlation between satisfaction and trust, found there is a positive correlation occurred between trust and satisfaction. Satisfaction is important antecedent to trust (Ercis et al., 2012). Brand satisfaction is essential for the constructing trust; brand satisfaction is a significant factor of brand trust (Cleopatra, 2015; Oliver, 1999; Schirmer et al., 2016). Based on the above literature, the hypothesis for this research suggested as follows:

H3: For domestic Smartphone brand, brand satisfaction has a direct positive impact on brand trust.

Brand loyalty is a multi-layered construct and was considered a dimensional concept with behavioural and attitudinal loyalty (Bowen and Chen, 2001). Behavioural loyalty is the willingness of the consumer to buy back the brand while the attitudinal loyalty is the consumer level of commitment towards the brand (Bobalca, Gatej and Ciobanu, 2012; Chaudhuri and Holbrook, 2001) for a better relationship with the brand, it is essential to build and maintain brand loyalty. Scholars who adopt a behavioural approach refer to brand loyalty, which is viewed operationally as repurchase intention and buying behaviour. It also includes frequency intensity and word of mouth (Baloglu, 2001). Researchers and scholars have also viewed brand loyalty in the light of attitudinal perspective measures; it indicates likeness and fondness towards brand through trust, commitment, and attachment (Baloglu, 2001; Bowen and Shoemaker, 2003; Morgan and Hunt, 1994a)

Although taking into consideration attitudinal aspects of loyalty allows the researcher to differentiate brand loyalty from repeat purchases but focuses on consumer declarations rather than actual purchases and may therefore not be an accurate demonstration of reality (Odin, Odin and Valette-Florence, 2001). Trust a critical component in creating brand loyalty (Morgan and Hunt, 1994b). Brand trust is considered a key factor in a long-term consumer relationship that can increase brand loyalty (Mazodier and Merunka, 2012). Some researchers believed that trust is a major determinant of brand loyalty, including attitudinal loyalty and behavioural loyalty and trusted brand purchased more frequently (Chaudhuri and Holbrook, 2001; Mazodier and Merunka, 2012). Previous researchers examined the link between brand trust and composite brand loyalty (Aydin and Ozer, 2005; Dehdashti et al., 2012). This study investigates the impact of brand trust on the behavioral and attitudinal dimension of brand loyalty in the context of domestic smartphones brand; therefore, we suggested that brand trust contributes to both attitudinal and behavioural loyalty in domestic Smartphone brands. Highly trusted domestic brands should purchase more frequently and should have a higher degree of attitudinal commitment.

H4 (a): For domestic Smartphone brands, brand trust has a direct positive impact on behavioural loyalty.

H4 (b): For domestic Smartphone brands, brand trust has a direct positive impact on attitudinal loyalty.

Trust shapes consumer behaviour through two different ways cognitive learning and consumer experience. The formation of trust formed through cognitive learning when the consumer does information activities and get awareness through information processing activities (like advertising) related to the benefits and attributes of the product. On the other hand, trust formed through experience when consumer purchases the product which suits their image and gets positive \& favourable results (Mowen and Minor, 1998). A brand trust is key element in developing the relationship with the consumer. Several studies examined the role of brand trust in determining brand loyalty; it indicates that consumer seek awareness through cognitive learning and it also portraits image in consumer's mind which enhance consumer trust on the brand (Chaudhuri and Holbrook, 2001). Likewise, satisfaction is also considered important antecedent of loyalty when satisfaction increases it leads the consumers towards loyalty (Bennett et al., 2005), the satisfaction-trust-loyalty sequence is the cornerstone of consumer 
loyalty behaviour (Tracey and Meredith, 2012). Gecti and Zengin (2013) investigate the trust-loyalty relationship and found that brand trust has positively influenced both attitudinal and behavioural loyalty. Many researchers are examined the brand trust as independent variable (Ahmed et al., 2014; Chaudhuri and Holbrook, 2001; Mirzaee eet al., 2013; Upamannyu et al., 2014) but fewer studies are examining brand trust as the mediator of the relationship in customer behaviour (Abd Aziz et al., 2018; Huang, 2017). This study posits that brand awareness, brand image, brand satisfaction positively affects the behavioural and attitudinal loyalty among young consumers towards domestic Smartphone brands through the mediation of brand trust.

Hypothesis 5 .

a) For domestic brands, the relationship between brand image and attitudinal loyalty mediated by brand trust.

b) For domestic brands, the relationship between brand awareness and attitudinal loyalty mediated by brand trust.

c) For domestic brands, the relationship between brand satisfaction and attitudinal loyalty mediated by brand trust.

Hypothesis 6.

a) For domestic brands, the relationship between brand image and behavioral loyalty mediated by brand trust.

b) For domestic brands, the relationship between brand awareness and behavioral loyalty mediated by brand trust.

c) For domestic brands, the relationship between brand satisfaction and behavioral loyalty mediated by brand trust.

Previous research has shown that individual characteristics influence their buying behaviour. Among the consumer characteristics, especially gender, have been identified as important elements in shaping consumer purchasing behaviour (Solomon, 2007; Wolters, 2014). Previous authors suggested gender is the strong predictor of consumer behaviour, followed by age, education, and income (Olli et al., 2001; Wolters, 2014). Men and Women both have different interests, needs, and different perception (Asteria et al., 2014). These differences occurred due to the different socialization development men and women experienced (Davidson and Freudenburg, 1996). According to the socialization theory that men and women experience different socialization process during their childhood, and both genders have developed diverse social values and expectation (Chodorow, 1979; Gilligan, 1982). Chen and Dhillon (2003), suggest gender drastically impact the perception of the capability, reliability, and goodwill of an Internet service provider, and thus, consumer confidence in e-commerce. Therefore, this study suggested gender is a significant moderator in the relationships between brand image, brand awareness, brand satisfaction, brand trust, and brand loyalty in the context of domestic Smartphone brands.

Methodology and research methods. Data for this research collected through self-administrated questioners. The questionnaires first developed in English then translated the multi-item scales into Chinese and then conducted a back-translation using two independent translators. Out of 200 surveys were distributed and restrained among full-time young students in a public university in Wuhan, 188 surveys were collected with 94 percent response rate by applying the convenience sampling technique. This sample size is sensible, as Roscoe (1975) indicated sample size lies between, 30-500 have measured satisfactory. The study sample for this study is young consumers because they are very much aware of the Smartphone brands and considered a member of a digital generation. Respondents were then asked to select brand in the category, and they were asked to think about this particular brand while completing the entire survey (Table 1). 
F. Zeng, M. Y. Bhutto, Y. A. Soomro. Chinese Smartphone Brands: Gender, Consumers Behavioural and Attitudinal Loyalty

Table 1. Major Questionnaire Items

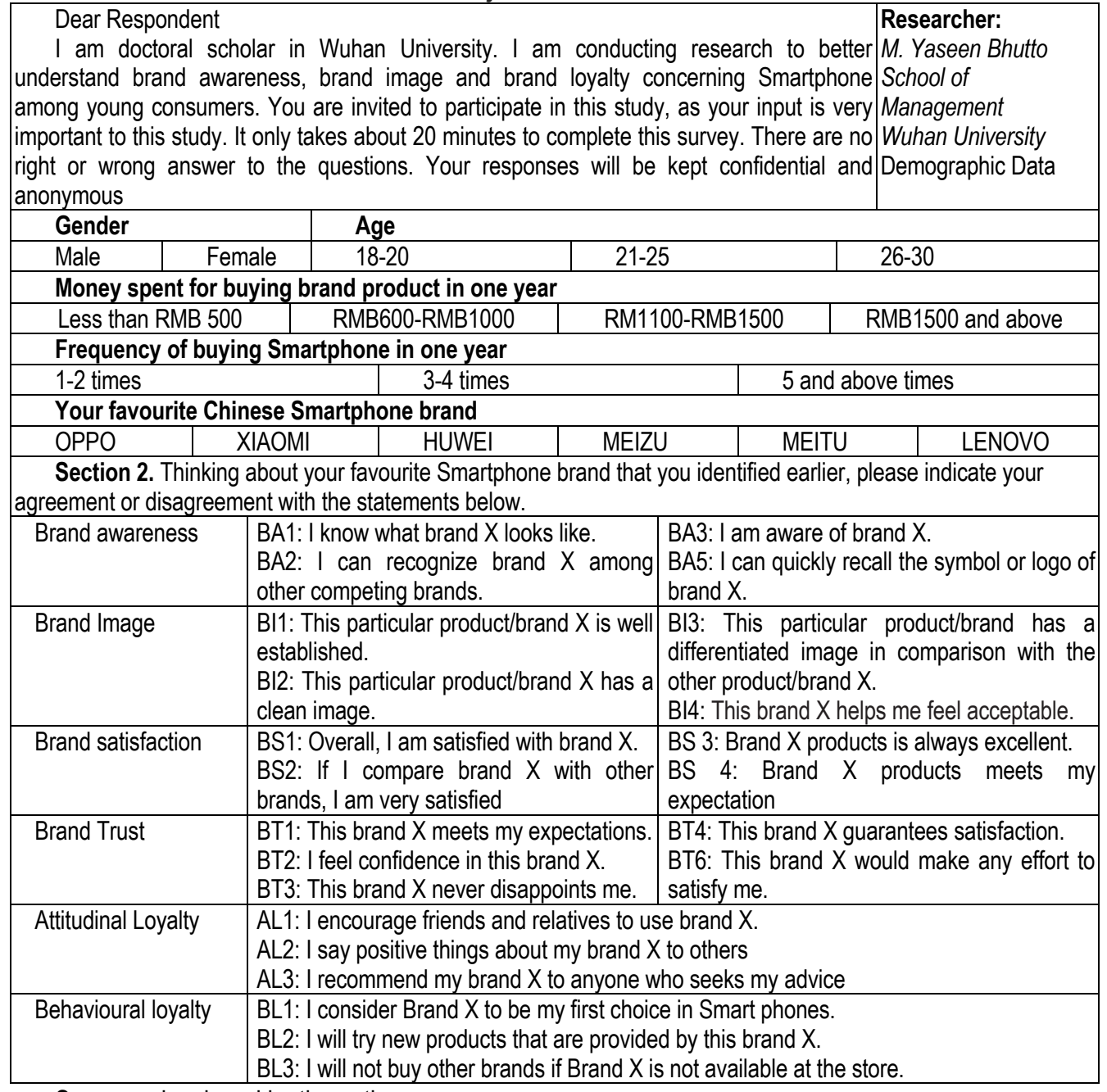

Sources: developed by the author.

Table 2 indicates the respondent experience with Chinese Smartphone brands. The respondent asked for details of their demographic information that includes gender and age and requested to provide their experience with the brand product itself.

The respondents were predominantly females (56\%) and (44\% male). About (41\%) respondent belongs to the age group of 18 to 20 , (55 percent) belongs to the age group of $21-25$ and ( 6 percent) belongs to the age group of 26-30. Table 2 also indicates the respondent's personal experience with the brand product it includes money spent on buying a brand product, the frequency of buying the brand, and favourite type of brand. The target population belongs to young consumers who are much updated about information technology and Smartphone brands. 
F. Zeng, M. Y. Bhutto, Y. A. Soomro. Chinese Smartphone Brands: Gender, Consumers Behavioural and Attitudinal Loyalty

Table 2. Demographics and consumer experience

\begin{tabular}{|l|c|c|}
\hline Gender of Respondents & Frequency & Percentage \\
\hline Male & 82 & 44 \\
\hline Female & 106 & 56 \\
\hline Total & 188 & 100 \\
\hline Age of Respondents & 78 & 41 \\
\hline $18-20$ & 104 & 55 \\
\hline $21-25$ & 6 & 6 \\
\hline $26-28$ & & 20 \\
\hline Money spent on buying a brand product & 37 & 22 \\
\hline Less than RMB 500 & 41 & 21 \\
\hline RMB600-RMB1000 & 39 & 38 \\
\hline RMB1100-RMB1500 & 71 & 100 \\
\hline greater than RMB 1600 & 188 & 91 \\
\hline Total & & 6 \\
\hline The frequency of buying in one year & 171 & 3 \\
\hline 1 time & 11 & \\
\hline 2 times & 6 & 10 \\
\hline 3 times & & 38 \\
\hline Type of favourite brand & 19 & 41 \\
\hline Oppo & 72 & 4 \\
\hline Xiaomi & 77 & 6 \\
\hline Huawei & 7 & 100 \\
\hline Meizu & 12 & \\
\hline Meitu & 1 & \\
\hline Lenovo & 188 & \\
\hline Total & & \\
\hline Sourcs: & & \\
\hline
\end{tabular}

Sources: developed by the author.

Results. To test our theoretical model, path modelling of the PLS-SEM (Partial Least Squares) with SmartPLS 3.0 software was used (Ringle, Wende and Becker, 2015). Factor Analysis it Table 2. The competence of the construct measurement evaluated through convergent validity, discriminant validity, and reliability. Statistical facts of convergent validity were determined by the individual high factor loadings and their statistical significance, and sufficient average variance (AVE) was extracted for each construct. As shown in Table 3, factor loading of all the items is greater than 0.55 . Furthermore, as shown in Table 3, the total AVEs significantly exceeded the proposed value of 0.5 (Hair, 2014). Therefore, this study concludes that the construct dimension shows sufficient convergent validity. Constructs also showed enough discriminant validity, since the square root of AVE for every construct is greater in all cases than the correlations between constructs (see Table 3).

Table 3. Factor loadings

\begin{tabular}{|c|c|c|}
\hline Construct & Items & Loadings \\
\hline \multirow{3}{*}{ Brand Image } & 2 & 3 \\
& $\mathrm{Bl} 1$ & 0.907 \\
\cline { 2 - 3 } & $\mathrm{BI} 2$ & 0.891 \\
\cline { 2 - 3 } & $\mathrm{B} \mid 3$ & 0.828 \\
\cline { 2 - 3 } & $\mathrm{Bl}$ & 0.778 \\
\hline
\end{tabular}


F. Zeng, M. Y. Bhutto, Y. A. Soomro. Chinese Smartphone Brands: Gender, Consumers Behavioural and Attitudinal Loyalty

Continue Tabl. 3

\begin{tabular}{|c|c|c|}
\hline 1 & 2 & 3 \\
\hline \multirow[t]{4}{*}{ Brand Satisfaction } & BS1 & 0.902 \\
\hline & BS2 & 0.919 \\
\hline & BS3 & 0.907 \\
\hline & BS4 & 0.873 \\
\hline \multirow[t]{4}{*}{ Brand Awareness } & BA1 & 0.830 \\
\hline & BA2 & 0.886 \\
\hline & BA3 & 0.828 \\
\hline & BA4 & 0.862 \\
\hline \multirow[t]{5}{*}{ Brand Trust } & BT1 & 0.838 \\
\hline & BT2 & 0.849 \\
\hline & BT3 & 0.751 \\
\hline & BT4 & 0.8 \\
\hline & BT5 & 0.818 \\
\hline \multirow[t]{3}{*}{ Attitudinal loyalty } & $\mathrm{AL} 1$ & 0.905 \\
\hline & AL2 & 0.905 \\
\hline & AL3 & 0.833 \\
\hline \multirow[t]{3}{*}{ Behavioural loyalty } & $\mathrm{BL} 1$ & 0.805 \\
\hline & BL2 & 0.755 \\
\hline & BL3 & 0.846 \\
\hline
\end{tabular}

Sources: developed by the author.

The findings of discriminant validity were presented in Table 4.

Table 4. Corelation matrix

\begin{tabular}{|l|c|c|c|c|c|c|}
\hline Relation & $\begin{array}{c}\text { Attitudinal } \\
\text { loyalty }\end{array}$ & $\begin{array}{c}\text { Behavioural } \\
\text { loyalty }\end{array}$ & $\begin{array}{c}\text { Brand } \\
\text { awareness }\end{array}$ & $\begin{array}{c}\text { Brand } \\
\text { image }\end{array}$ & $\begin{array}{c}\text { Brand } \\
\text { satisfaction }\end{array}$ & $\begin{array}{c}\text { Brand } \\
\text { trust }\end{array}$ \\
\hline Attitudinal loyalty & 0.882 & & & & & \\
\hline Behavioural loyalty & 0.688 & 0.803 & & & & \\
\hline Brand awareness & 0.294 & 0.476 & 0.852 & & & \\
\hline Brand image & 0.374 & 0.574 & 0.735 & 0.852 & & \\
\hline Brand satisfaction & 0.455 & 0.689 & 0.652 & 0.71 & 0.9 & \\
\hline Brand trust & 0.604 & 0.695 & 0.559 & 0.663 & 0.71 & 0.812 \\
\hline
\end{tabular}

Sources: developed by the author.

The results of reliability and validity were presented in Table 5 . Reliability of each construct was examined through the composite reliability and Cronbach's $\alpha$. The reliability indicators of the constructs in this study are shown in Table 5. All values meet the accepted standard suggested by (Hair et al., 2015), it indicates that the measurement model reliable and meaningful.

In the investigation a PLS bootstrapping method (Fig. 2) with the number of bootstrap samples of 5000 and 330 cases to assess the significance of the path coefficient was applied (Sarstedt, Ringle and Hair, 2017). Table 6 assesses the full structural model. 
F. Zeng, M. Y. Bhutto, Y. A. Soomro. Chinese Smartphone Brands: Gender, Consumers Behavioural and Attitudinal Loyalty

Table 5. Cronbach's Alpha, Composite Reliability, Average Variance Extracted

\begin{tabular}{|l|c|c|c|}
\hline Construct & Cronbach's Alpha & Composite Reliability & $\begin{array}{c}\text { Average Variance } \\
\text { Extracted (AVE) }\end{array}$ \\
\hline Brand image & 0.873 & 0.914 & 0.727 \\
\hline Brand satisfaction & 0.922 & 0.945 & 0.811 \\
\hline Brand awareness & 0.874 & 0.914 & 0.726 \\
\hline Brand trust & 0.871 & 0.906 & 0.66 \\
\hline Attitudinal loyalty & 0.868 & 0.913 & 0.778 \\
\hline Behavioural loyalty & 0.723 & 0.844 & 0.645 \\
\hline
\end{tabular}

Sources: developed by the author.

The model run was presented in Figure 2.

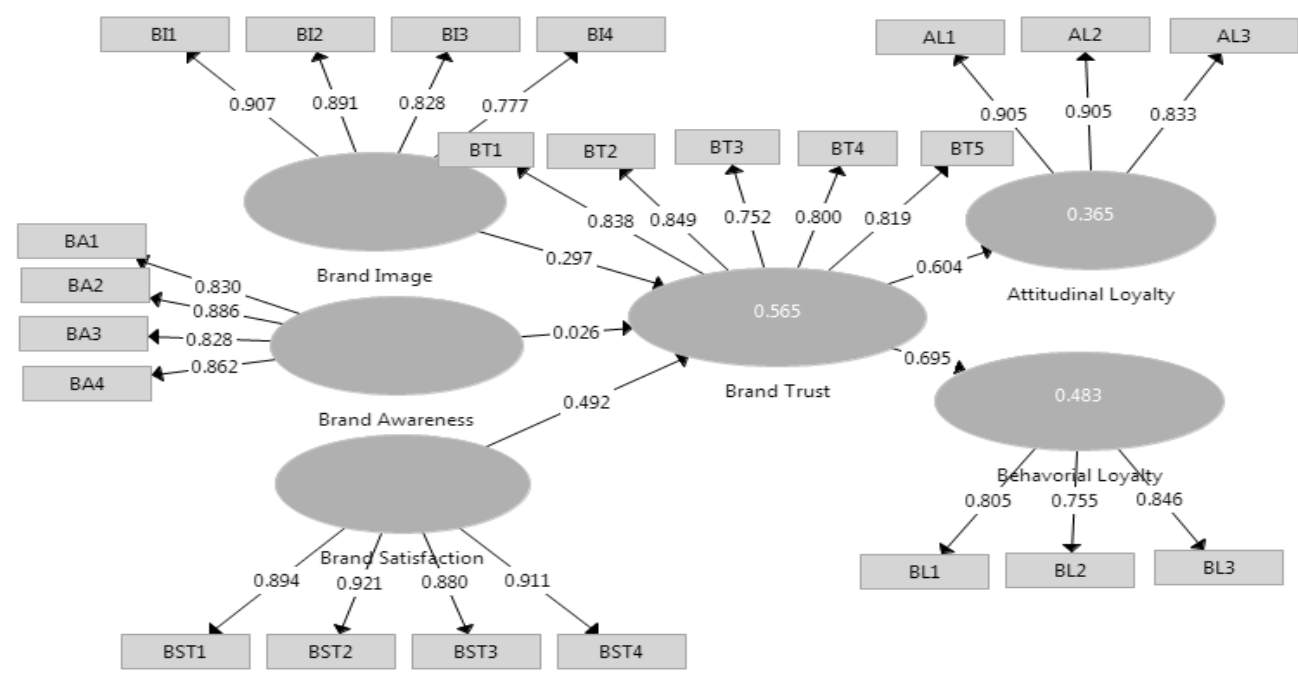

Sources: developed by the author.

Figure 2. The path diagram of a model run

Hypothesis 1 predicted that brand Image has a positive relation to brand trust. The results in Table 6 show that there is a positive link between brand image and brand trust $(\beta=0.309, t=3.369, P=0.001)$. As demonstrated in Table 5 that there is a non-significant relationship between brand awareness and brand trust $(\beta=0.021, t=0.235, P=0.815)$. Therefore, Hypothesis 2 has not supported. For Hypothesis 3 , the results indicated that there is a positive link between brand satisfaction and brand trust $(\beta=0.477$, $t=5.979, P=0.000)$. Thus, Hypothesis 3 has supported. Last but not the least, Hypothesis 4(a) and 4(b) revealed that there is a positive bond between brand trust and attitudinal loyalty $(\beta=0.604, t=13.135$, $P=0.000)$ and also positive bond existence between brand trust and behavioural loyalty $(\beta=0.695$, $t=17.042, P=0.000)$.

Hypothesis 5(a) predicted that a significant mediation effect of brand trust would be the link between brand image and attitudinal loyalty, the findings revealed in Table $7(t=3.3422, P=0.0004)$. Thus, Hypothesis 5(a) has supported. Table 7 demonstrates that brand trust failed to mediate the relationship between brand awareness and attitudinal loyalty statistically $(t=0.234, P=0.815)$. Hence, Hypothesis $5(b)$ has not supported. 
F. Zeng, M. Y. Bhutto, Y. A. Soomro. Chinese Smartphone Brands: Gender, Consumers Behavioural and Attitudinal Loyalty

Table 6. Hypotheses Assessment Summary (direct paths)

\begin{tabular}{|l|c|c|c|c|c|}
\hline Hypothesis & Relation & Beta & T-Value & P-Value & Findings \\
\hline H1 & BI-BT & 0.309 & 3.369 & 0.001 & Supported \\
\hline H2 & BA-BT & 0.021 & 0.235 & 0.815 & Not Supported \\
\hline H3 & BS-BT & 0.477 & 5.979 & 0.000 & Supported \\
\hline H4(a) & BT-AL & 0.604 & 13.135 & 0.000 & Supported \\
\hline H4(b) & BT-BL & 0.695 & 17.042 & 0.000 & Supported \\
\hline
\end{tabular}

Note: $\mathrm{Bl}=$ brand image, $\mathrm{BT}=$ brand trust, $\mathrm{BA}=$ brand awareness, $\mathrm{BS}=$ brand satisfaction, $\mathrm{BL}=$ behavioural loyalty, $\mathrm{AL}=$ attitudinal loyalty.

Sources: developed by author

However, the results showed a significant mediating effect of brand trust on the link between brand satisfaction and attitudinal loyalty $(\mathrm{t}=5290, \mathrm{P}=0.000)$, supporting Hypothesis $5(\mathrm{c})$. Considering the behavioural aspect, there is a significant mediating effect of brand trust in the link between brand image and behavioural loyalty, the findings revealed in Table 7 ( $t=3.321, P=0.001)$. Thus, Hypothesis $6(a)$ has supported. Table 7 demonstrates that brand trust failed to mediate the relationship between brand awareness and behavioural loyalty statistically $(t=0.234, P=0.815)$. Hence, Hypothesis $6(b)$ has not supported. However, the results showed a significant mediating effect of brand trust on the link between brand satisfaction and behavioural loyalty $(t=5.173, P=0.000)$, supporting Hypothesis $6(\mathrm{c})$. Table 7 assesses the results of the mediation effect.

Table 7. Hypotheses Assessment Summary (Mediating indirect Paths)

\begin{tabular}{|l|c|c|c|c|}
\hline Hypothesis & Path & T-Value & P-Value & Findings \\
\hline $\mathrm{H} 5(\mathrm{a})$ & $\mathrm{BI} \rightarrow \mathrm{BT} \rightarrow \mathrm{AL}$ & 3.178 & 0.001 & Supported \\
\hline $\mathrm{H} 5(\mathrm{~b})$ & $\mathrm{BA} \rightarrow \mathrm{BT} \rightarrow \mathrm{AL}$ & 0.234 & 0.815 & Not Supported \\
\hline $\mathrm{H} 5(\mathrm{c})$ & $\mathrm{BS} \rightarrow \mathrm{BT} \rightarrow \mathrm{AL}$ & 5.290 & 0.000 & Supported \\
\hline $\mathrm{H} 6(\mathrm{a})$ & $\mathrm{Bl} \rightarrow \mathrm{BT} \rightarrow \mathrm{BL}$ & 3.321 & 0.001 & Supported \\
\hline $\mathrm{H} 6(\mathrm{~b})$ & $\mathrm{BA} \rightarrow \mathrm{BT} \rightarrow \mathrm{BL}$ & 0.234 & 0.815 & Not Supported \\
\hline $\mathrm{H} 6(\mathrm{c})$ & $\mathrm{BS} \rightarrow \mathrm{BT} \rightarrow \mathrm{BL}$ & 5.173 & 0.000 & Supported \\
\hline
\end{tabular}

NOTE: BI=brand image, BT=brand trust, BA=brand awareness, BS=brand Satisfaction, BL=behavioural loyalty, $\mathrm{AL}=$ attitudinal loyalty.

Sources: developed by author.

The moderation role of gender has tested by the multi-group analysis in SmartPLS 30 . The two groups comprised of male and female. For both groups, the SRMR value is below 0.09 , which gives a good fit. The results have shown in Table 8.

Table 8. Moderating effect

\begin{tabular}{|l|c|c|c|c|}
\hline & \multicolumn{2}{|c|}{ Men } & \multicolumn{2}{c|}{ Female } \\
\hline Relation & T-Value & P-Value & T-Value & P-Value \\
\hline Brand Awareness -> Brand Trust & 1.064 & 0.287 & 1.218 & 0.223 \\
\hline Brand Image -> Brand Trust & 4.85 & 0.000 & 1.095 & 0.273 \\
\hline Brand Satisfaction -> Brand Trust & 2.978 & 0.003 & 5.554 & 0.000 \\
\hline Brand Trust -> Attitudinal Loyalty & 8.778 & 0.000 & 10.231 & 0.000 \\
\hline Brand Trust -> Behavioural Loyalty & 14.302 & 0.000 & 12.49 & 0.000 \\
\hline
\end{tabular}

Sources: developed by author. 

Loyalty

The outcome has shown (Table 8) that there are significant differences between both group, the tvalue associated to the impact of brand awareness on brand trust in both group (male \& female) is insignificant. The significant positive impact of brand image on brand trust in male group $(\mathrm{t}=4.85$, $P=0.000)$ but in the female group there is an insignificant impact of brand image on brand trust $(t=1.095$, $P=0.273)$. In addition, the impact of brand satisfaction on brand trust in the female group ( $t=5.554$, $\mathrm{P}=0.000)$ is greater than the male group $(\mathrm{t}=2.978, \mathrm{P}=0.003)$. The impact of brand trust on attitudinal loyalty is significant in both male and female group, but the impact of brand trust on attitudinal loyalty is higher in female group $(t=10.231, P=0.000)$ than the male group $(t=8.778, P=0.000)$. Last but not least the impact of brand trust on behavioural loyalty is significant in both male and female group, but the impact of trust on behavioural loyalty is higher in male group $(t=14.302, P=0.000)$ than the female group $(t=12.49, P=0.000)$.

Conclusions. This study addresses gender differences; the result in Table 8 indicates that the impact of brand image on brand trust is significant in the male group but insignificant in the female group. It means brand image of domestic brands successfully creating trust in the male group but failed to establish trust in the female group. The reason might be marketing campaigns and advertisements fails to entertain and convinced the female consumers towards their brands, so the practitioners and marketers need to create an effective marketing strategy that can cater to both the gender. Also results in table8 found that brand satisfaction on brand trust is higher in the female group than the male group. It indicates that Chinese female consumers more satisfied with domestic brands than the male group, the reason might be female consumer more concerned about brand looks and symbolic values and male more concerned about functional values. The impact of brand trust on attitudinal loyalty is higher in the female group than the male group; it indicates that female consumers having more trust on domestic brands and female consumer spread more positive word of mouth in their peer groups and friends \& family and the domestic brand has enough values and benefits. The impact of brand trust on behavioural loyalty is higher in the male group than the female group; it indicates that brand trust positively affects the behavioural loyalty in men, it indicates that men used to buy more frequently than women. For example, Companies like Apple have the best of both worlds. As you buy more i-Devices and become more dependent on iCloud, switching to Android becomes harder (behavioural).

The $\mathrm{H} 1$ relationship between brand Image and brand trust found significant. The findings revealed that young Chinese Consumers highly trust the brand image of the domestic Chinese Smartphone brand. It means that Chinese consumers are more likely interested in buying the Chinese Smartphone brands which have been successful in creating a better brand image in the minds of consumers and trust towards the brand. $\mathrm{H} 2$ relationship between brand awareness and brand trust found to be insignificant, it indicates that brand awareness regarding Chinese Smartphone brands among young Chinese consumers does not enhance their trust the reason can be ineffective marketing and advertising campaigns. $\mathrm{H} 3$ relationship between brand satisfaction and brand trust found to be significant, it indicates that when consumer are satisfied with quality and features of the product, it enhances \& increases the trust of Chinese consumer towards Chinese Smartphone brands. H4(a) relationship between brand trust and attitudinal loyalty found to be significant; it indicates that Chinese consumer has trust in domestic brands, and it increases their attitudinal commitment. $\mathrm{H} 4(\mathrm{~b})$ relationship between brand trust and behavioral loyalty found to be significant; it means brand trust positively affect behavioral loyalty of Chinese consumer, which encourage them to purchase the trusted brand more frequently.

$\mathrm{H} 5$ (a) and $\mathrm{H} 6$ (a) stated that brand trust mediates the relationship between brand image and attitudinal \& behavioral loyalty. It indicates brand trust has positive mediation in the link between brand image and attitudinal \& behavioral loyalty; it shows brand image found to be a significant factor of brand trust, therefore, constraining customers from exhibiting attitudinal \& behavioral loyalty towards the domestic Smartphone brands. The success of brand trust to mediate the relationship between brand 

Loyalty

image and attitudinal \& behavioral loyalty might be because of domestic Smartphone brand can build the consumer trust towards their brand. As the consumer believed, that domestic brand creates enough value for them to trust the brand. As a result, attitudinal \& behavioral loyalty towards the brand developed. $\mathrm{H} 5(\mathrm{~b})$ and $\mathrm{H} 6(\mathrm{~b})$ stated that brand trust does mediate the relationship between brand awareness and attitudinal \& behavioral loyalty but the findings state that brand trust does not mediate the relationship between brand awareness and attitudinal \& behavioural loyalty, it means brand awareness found to be an insignificant factor of brand trust in creating attitudinal \& behavioural loyalty. The reason can be ineffective marketing campaigns, and advertisements failed to build brand awareness among young Chinese consumers. Hypothesis $\mathrm{H} 5$ (c) and $\mathrm{H} 6$ (c) stated that brand trust (BT) mediates the relationship between brand satisfaction and attitudinal \& behavioural loyalty. As expected, brand trust had a full meditation on the connection between brand satisfaction and attitudinal \& behavioral loyalty. In other words, brand trust is a mechanism that transfers the effects of brand satisfaction on attitudinal \& behavioral loyal, which increase frequent buying and attitudinal commitment. Thus, this finding is to emphasize that there is the synergetic effect of brand satisfaction on attitudinal loyalty of young Chinese consumers towards domestic Smartphone brands.

The purpose of this study was to examine the variables which affecting attitudinal \& behavioral loyalty among young Chinese consumer. The reason behind this study was to understand the mechanism that explains the development of brand loyalty considering the domestic brands. The result of this research indicated that brand image and brand satisfaction both have direct and mediating effects in creating brand loyalty to domestic brands. The study found the importance of brand trust in helping us understand how young Chinese consumers develop loyalty towards domestic brands. In addition this study also investigates gender differences, the impact of brand image on brand trust is less significant in the female gender, the impact of satisfaction on brand trust more in male gender in comparison of the female gender, attitudinal loyalty is high in female gender but behavioral loyalty is slightly less in comparison to the male gender. Taken as a whole, the findings suggest that customers will be loyal when the Smartphone brands companies offer a good image and quality, awareness, satisfy the need of consumers, and let the consumers trust their brands.

The mobile phone industry is a fast-changing industry with a vibrant mobile phone market. A large part of the population is changing due to rapid changes in technology and the short lifespan of mobile phones. Understanding the importance of brand loyalty would, therefore, be one of the key success factors for companies in the near future. Traditionally, researchers usually focus and investigate the loyalty of global or international brands; we recommended that researchers should pay a similar amount of attention to the domestic brands as well. This study contributes by utilizing the available knowledge on brand loyalty about domestic Smartphone brands. Secondly, this study investigates the loyalty of young Chinese towards Chinese smartphone brand, young grown-up consumers in China has been found to enjoy a higher propensity to spend (Liu, 2002) and focus increasingly on brands (Kwan, Yeung and Au, 2003). This can be productive when it comes to understanding consumer behaviour in a changing environment. The market is considered to be an unstable and short time frame. The product life cycle is shorter, and new entrants can enter into the severe competition. Brand loyalty is essential for domestic Smartphone industry to make sure that consumers remember its brands/products and will not go to other rival foreign brands as the Iphone (American Brand) and Samsung (Korean Brand). The finding of this study helps managers to understand the role of domestic brands in Smartphone industry of China. In addition, this study suggests domestic brands also keep an eye on foreign brands and develop their strategies efficiently and effectively so they can easily compete with international brands. The study also suggests that executives and managers understand the changes in the business environment; it can be beneficial for a business to retain loyal customers and increase sales shortly. 
This study has some limitations that should be considered while interpreting the findings. The first one is generalizability. This study limited to the domestic Smartphone brands; the results may not be generalizable to the other brands. The quantitative methods were also used to carry out this study; however, the author may apply both quantitative and qualitative research methods in the near future. Furthermore, the sample size is minimal, and data for this research collected from one city, Wuhan China. It is essential for future studies to collect the data from different cities of China, and future studies can be strengthening by increasing sample size. Also, future research can consider other factors such as brand Value, brand attitude, and brand attachment to understand attitudinal \& behavioural loyalty. This study entertains gender differences; however, future research can consider other demographics variables like age, income to understand attitudinal \& behavioural loyalty. This study focuses on attitudinal and behavioural loyalty; furthermore, empirical researchers should conduct to understand composite loyalty.

Author Contributions. Y.B. presented and conceptualized the idea and wrote the proposal for this paper. Z.F. assessed proposal and first draft was prepared. Later Y.A.S. joined and the team divided the work. Z.F. administrated the project and acquired project funding. Y.A.S. was involved in the literature review along with Y.B. Questionnaire developed by Yaseen Bhutto and revised by Y.A.S. Later, it was translated into Chinese by Z.F. Data analysis performed by Y.B. Interpretation, discussion and conclusion was joint effort of the team. Finally, all authors revised, discussed and approved the manuscript.

Funding. The authors acknowledge the support from the National Natural Science Foundation of China (grant number 71832010, 71832004 \& 91646121, Key Program).

\section{References}

Abd Aziz, S., Jusoh, M. S., \& Amlus, H. (2018). An Investigation on The Mediating Effect of Brand Trust on the Relationship between Elements of Brand Management and Brand Loyalty: A Literature Review. Middle-East Journal of Scientific Research, 26 (1), 27-34, DOI: 10.5829/idosi.mejsr.2018.27.34

Ahmed, Z., Rizwan, M., Ahmad, M., \& Haq, M. (2014). Effect of brand trust and customer satisfaction on brand loyalty in Bahawalpur. Journal of Sociological Research, 5(1), 306-326. DOI: 10.5296/jsr.v5i1.6568

Akdeniz Ar, A., \& Kara, A. (2014). Emerging market consumers' country of production image, trust and quality perceptions of global brands made-in China. Journal of Product \& Brand Management, 23(7), 491-503,:10.1108/JPBM-12-2013-0472

Algesheimer, R., Dholakia, U. M., \& Herrmann, A. (2005). The Social Influence of Brand Community: Evidence from European Car Clubs. Journal of Marketing, 69(3), 19-34. DOI: 10.1509/jmkg.69.3.19.66363

Alhaddad, A. ( 2015). A structural model of the relationships between brand image, brand trust and brand loyalty. International Journal of Management Research \& Review, 5(3), 137-144

Al-Hawary, S. I. S. (2013). The roles of perceived quality, trust, and satisfaction in predicting brand loyalty: the empirical research on automobile brands in Jordan market. International Journal of Business Excellence, 6(6), 656-686.

Ashley, C., \& Leonard, H. A. (2009). Betrayed by the Buzz? Covert Content and Consumer-Brand Relationships. Journal of Public Policy \& Marketing, 28(2), 212-220. DOI: 10.1509/jppm.28.2.212

Asteria, D., Suyanti, E., Utari, D. \& Wisnu, D. (2014). Model of Environmental Communication with Gender Perspective in Resolving Environmental Conflict in Urban Area (Study on the Role of Women's Activist in Sustainable Environmental Conflict Management). Procedia Environmental Sciences, 20, 553-562. DOI: https://DOI.org/10.1016/j.proenv.2014.03.068

Aydin, S., \& Ozer, G. (2005). The analysis of antecedents of customer loyalty in the Turkish mobile telecommunication market. European Journal of Marketing, 39(7/8), 910-925. DOI: 10.1108/03090560510601833

Bai, H., Wang, J., \& Zeng, A. Z. (2018). Exploring Chinese consumers' attitude and behavior toward smartphone recycling. Journal of Cleaner Production, 188, 227-236. DOI: https://DOI.org/10.1016/j.jclepro.2018.03.253

Baloglu, S. B., S. (2001). An Investigation of a Loyalty Typology and the Multidestination Loyalty of International Travelers. Tourism Analysis, 6(1), 41-52.

Bennett, R., Hartel, C. E. J., \& McColl-Kennedy, J. R. (2005). Experience as a moderator of involvement and satisfaction on brand loyalty in a business-to-business setting 02-314R. Industrial Marketing Management, 34(1), 97-107.

Bobalca, C., Gatej, C., \& Ciobanu, O. (2012). Developing a Scale to Measure Customer Loyalty. Procedia Economics and Finance, 3, 623-628. DOI: https://DOl.org/10.1016/S2212-5671(12)00205-5

Bowen, J. T., \& Chen, S. L. (2001). The relationship between customer loyalty and customer satisfaction. International journal of contemporary hospitality management, 13(5), 213-217. 
F. Zeng, M. Y. Bhutto, Y. A. Soomro. Chinese Smartphone Brands: Gender, Consumers Behavioural and Attitudinal Loyalty

Bowen, J. T., \& Shoemaker, S. (2003). Loyalty: A Strategic Commitment. Cornell Hotel and Restaurant Administration Quarterly, 44(5-6), 31-46. DOI: 10.1177/001088040304400505

Chaudhuri, A., \& Holbrook, M. B. (2001). The Chain of Effects from Brand Trust and Brand Affect to Brand Performance: The Role of Brand Loyalty. Journal of Marketing, 65(2), 81-93. DOI: 10.1509/jmkg.65.2.81.18255

Chen, S. C., \& Dhillon, G. S. (2003). Interpreting Dimensions of Consumer Trust in E-Commerce. Information Technology and Management, 4(2), 303-318. DOI: 10.1023/A:1022962631249

Chen, Y.-S. (2010). The Drivers of Green Brand Equity: Green Brand Image, Green Satisfaction, and Green Trust. Journal of Business Ethics, 93(2), 307-319. DOI: 10.1007/s10551-009-0223-9

Chien, T. K., Chang, T. H., \& Su, C. T. (2003). Did your efforts really win customers' satisfaction? Industrial Management \& Data Systems, 103(4), 253-262. DOI: DOI:10.1108/02635570310470647

Chodorow, N. J. (1999). The reproduction of mothering: Psychoanalysis and the sociology of gender. Univ of California Press Cleopatra, V. (2015). Brand evaluation, satisfaction and trust as predictors of brand loyalty: the mediator-moderator effect of brand relationships. Journal of Consumer Marketing, 32(6), 405-421. DOI: 10.1108/JCM-02-2014-0878

Davidson, D. J., \& Freudenburg, W. R. (1996). Gender and Environmental Risk Concerns: A Review and Analysis of Available Research. Environment and Behavior, 28(3), 302-339. DOI: 10.1177/0013916596283003

Dehdashti, Z., Kenari, M., \& Bakhshizadeh, A. (2012). The impact of social identity of brand on brand loyalty development. Management Science Letters, 2(4), 1425-1434.

Ercis, A., Unal, S., Candan, F. B., \& Yıldirım, H. (2012). The Effect of Brand Satisfaction, Trust and Brand Commitment on Loyalty and Repurchase Intentions. Procedia - Social and Behavioral Sciences, 58, 1395-1404.

Esch, F. R., Langner, T., Schmitt, B. H., \& Geus, P. (2006). Are brands forever? How brand knowledge and relationships affect current and future purchases. Journal of Product \& Brand Management, 15(2), 98-105.

Fleck, N., Korchia, M., \& Le Roy, I. (2012). Celebrities in Advertising: Looking for Congruence or Likability? Psychology \& Marketing, 29(9), 651-662. DOI: 10.1002/mar.20551

Florence, K., \& Catherine, V. (2012). How store brands build retailer brand image. International Journal of Retail \& Distribution Management, 40(7), 528-543. DOI: 10.1108/09590551211239846

Fullerton, G. (2005). The Impact of Brand Commitment on Loyalty to Retail Service Brands. Canadian Journal of Administrative Sciences / Revue Canadienne des Sciences de l'Administration, 22(2), 97-110.

Gecti, F., \& Zengin, H. (2013). The Relationship between Brand Trust, Brand Affect, Attitudinal Loyalty and Behavioral Loyalty: A Field Study towards Sports Shoe Consumers in Turkey. International Journal of Marketing Studies, 5.

Gilligan, C. (1982). In a Different Voice: Psychological Theory and Women's Development: Harvard University Press, N.Y

Guo, X., \& Yan, K. (2017). Estimation of obsolete cellular phones generation: A case study of China. The Science of the total environment, 575, 321-329. DOI: 10.1016/j.scitotenv.2016.10.054

Ha, H.-Y. (2004). Factors influencing consumer perceptions of brand trust online (Vol. 13).

Hair, J., W. Black, B. Babin, and R. Anderson. (2014). Multivariate Data Analysis: Pearson New International Edition. (7th

ed.): New Jersey: Pearson/Prentice Hall.

Hess, J., \& Story, J. (2005). Trust-based commitment: Multidimensional consumer-brand relationships (Vol. 22).

Huang, C. C. (2017). The impacts of brand experiences on brand loyalty: mediators of brand love and trust. Management Decision, 55(5), 915-934.

ITU Annual Reports. (2015): ITU Library and Archives Service.

Jaiswal, D., \& Kant, R. (2018). Green purchasing behaviour: A conceptual framework and empirical investigation of Indian consumers. Journal of Retailing and Consumer Services, 41, 60-69. DOI: https://DOl.org/10.1016/j.jretconser.2017.11.008

Jeff, H., \& John, S. (2005). Trust-based commitment: multidimensional consumer-brand relationships. Journal of Consumer

Marketing, 22(6), 313-322. DOI: 10.1108/07363760510623902

John, T. B., \& Shiang-Lih, C. (2001). The relationship between customer loyalty and customer satisfaction. International Journal of Contemporary Hospitality Management, 13(5), 213-217. DOI: 10.1108/09596110110395893

Jumiati, S., \& Norazah Mohd, S. (2015). Young consumers' insights on brand equity: Effects of brand association, brand loyalty, brand awareness, and brand image. International Journal of Retail \& Distribution Management, 43(3), 276-292.

Kabiraj, S., \& Joghee, S. (2011). Development of a conceptual framework for brand loyalty: A Euro-Mediterranean perspective (Vol. 18).

Kara, C., Yu Leung, N., \& Edwin, K. L. (2013). Impact of celebrity endorsement in advertising on brand image among Chinese adolescents. Young Consumers, 14(2), 167-179. DOI: 10.1108/17473611311325564

Kwan, C. Y., Yeung, K. W., \& Au, K. F. (2003). A statistical investigation of the changing apparel retailing environment in China. Journal of Fashion Marketing and Management: An International Journal, 7(1), 87-100. DOI: 10.1108/13612020310464395

Lau, G. T., \& Lee, S. H. (1999). Consumers' Trust in a Brand and the Link to Brand Loyalty. Journal of Market-Focused Management, 4(4), 341-370. DOI: 10.1023/A:1009886520142

Lee, K. (2009). Gender differences in Hong Kong adolescent consumers' green purchasing behavior. Journal of Consumer

Marketing, 26(2), 87-96. DOI: 10.1108/07363760910940456

Liu, W.-L. (2002). Advertising in China: Product branding and beyond (Vol. 7).

Mabkhot, H. (2016). The Direct and Indirect Influence of Brand Image, Brand Experience, and Brand Personality on Brand Loyalty.

Mazodier, M., \& Merunka, D. (2012). Achieving brand loyalty through sponsorship: the role of fit and self-congruity. Journal of the Academy of Marketing Science, 40(6), 807-820. 
MIIT Report. (2016). Ministry of Industry and Information Technology China.

Mirzaee, N., Rad, M. K., \& Molavi, N. (2013). An examination of the effect of brand's dimensions on loyalty of industrial customers. Journal of Research and Development, 187(941), 1-14.

Morgan, R., \& Hunt, S. (1994a). The Commitment-Trust Theory of Relationship Marketing. journal of marketing, 58, 20-38.

Morgan, R., \& Hunt, S. (1994b). The Commitment-Trust Theory of Relationship Marketing (Vol. 58).

Mowen, J.C. and Minor, M. (1998). Consumer Behavior: Prentice Hall.

Nezakati, H., Kok, K.O. \& Asgari, O. (2011). Do Consumer based-factors influence consumer buying behavior in automotive industry?(Malaysia Evidence). Paper presented at the International Proceedings of Economics Development \& Research, 10.

Odin, Y., Odin, N., \& Valette-Florence, P. (2001). Conceptual and operational aspects of brand loyalty: an empirical investigation. Journal of Business Research, 53(2), 75-84. DOI: https://DOl.org/10.1016/S0148-2963(99)00076-4

Oliver, R. L. (1999). Whence Consumer Loyalty? Journal of Marketing, 63, 33-44. DOI: 10.2307/1252099

Olli, E., Grendstad, G., \& Wollebaek, D. (2001). Correlates of Environmental Behaviors: Bringing Back Social Context. Environment and Behavior, 33(2), 181-208. DOI: 10.1177/0013916501332002

Ongondo, F. O., \& Williams, I. D. (2011). Greening academia: Use and disposal of mobile phones among university students. Waste Management, 31(7), 1617-1634. DOI: https://DOl.org/10.1016/j.wasman.2011.01.031

Panchal, S. K., Khan, B. M., \& Ramesh, S. (2012). Importance of 'brand loyalty, brand awareness and perceived quality parameters' in building brand equity in the Indian pharmaceutical industry. Journal of Medical Marketing, 12(2), 81-92.

Rajat, R., \& Fazlul, K. R. (2015). Antecedents and consequences of self-congruity. European Journal of Marketing, 49(3/4), 444-466. DOI: 10.1108/EJM-12-2013-0739

Reichheld, F. F., Markey Jr, R. G., \& Hopton, C. (2000). The loyalty effect - The relationship between loyalty and profits (12). Richard, C. (2016). Brand communication, brand image and brand trust as antecedents of brand loyalty in Gauteng Province

of South Africa. African Journal of Economic and Management Studies, 7(1), 124-139. DOI: 10.1108/AJEMS-03-2013-0031 Ringle, C. M., Wende, S., \& Becker, J. M. (2015). SmartPLS 3. Boenningstedt: SmartPLS GmbH.

Rio, A. B. d., Rodolfo, V., \& Victor, I. (2001). The effects of brand associations on consumer response. Journal of Consumer

Marketing, 18(5), 410-425. DOI: 10.1108/07363760110398808

Roscoe, J. T. (1975). Fundamental research statistics for the behavioral sciences [by] John T. Roscoe.

Sahin, A., Zehir, C., \& Kitapçı, H. (2011). The Effects of Brand Experiences, Trust and Satisfaction on Building Brand Loyalty; An Empirical Research On Global Brands. Procedia - Social and Behavioral Sciences, 24, 1288-1301.

Sarstedt, M., Ringle, C. M., \& Hair, J. F. (2017). Partial Least Squares Structural Equation Modeling. In C. Homburg, M.

Klarmann \& A. Vomberg (Eds.), Handbook of Market Research (pp. 1-40). Cham: Springer International Publishing.

Sasmita, J., \& Mohd Suki, N. (2015). Young consumers' insights on brand equity: Effects of brand association, brand loyalty, brand awareness, and brand image. International Journal of Retail \& Distribution Management, 43(3), 276-292.

Schirmer, N., Ringle, C. M., Gudergan, S. P., \& Feistel, M. S. G. (2016). The link between customer satisfaction and loyalty: the moderating role of customer characteristics. Journal of Strategic Marketing, 1-20. DOI: 10.1080/0965254X.2016.1240214 Schuiling, I., \& Kapferer, J.-N. (2004). Executive Insights: Real Differences Between Local and International Brands: Strategic Implications for International Marketers. Journal of International Marketing, 12(4), 97-112. DOI: 10.1509/jimk.12.4.97.53217

Schultz, D. E., Block, M. P., \& Viswanathan, V. (2014). Brand preference being challenged. Journal of Brand Management, 21(5), 408-428. DOl: 10.1057/bm.2014.5

Sean Hyun, S., \& Kim, W. (2011). Dimensions of brand equity in the chain restaurant industry. Cornell Hospitality Quarterly, 52(4), 429-437.

Solomon, M. R. (2007). Consumer Behavior: Buying, Having, and Being (Vol. 7): Prentice-Hall,Upper Saddle River, N.

Sze, L. H. H., N. (2012). Brand equity in automotive sector. Paper presented at the Paper presented at the Proceedings of the 2nd International Conference on Management, Malaysia.

Thwaites, D., Lowe, B., Monkhouse, L. L., \& Barnes, B. R. (2012). The Impact of Negative Publicity on Celebrity Ad Endorsements. Psychology \& Marketing, 29(9), 663-673. DOI: 10.1002/mar.20552

Tracey, S. D., \& Meredith, E. D. (2012). Uncovering the real effect of switching costs on the satisfaction-loyalty association: The critical role of involvement and relationship benefits. European Journal of Marketing, 46(3/4), 447-468.

Tsai, J. P., \& Ho, C. F. (2013). Does design matter? Affordance perspective on smartphone usage. Industrial Management \& Data Systems, 113(9), 1248-1269.

Upamannyu, N. K., C. Gulati and G. Mathur. (2014). Effect of Brand Trust, Brand Image on Customer knowledge on the mediating role of brand trust in the Brand Loyalty in FMCG Sector at Gwalior Region. International Refereed Multidisciplinary Journal of Therefore, to bridge these significant gaps, this paper will Contemporary Research., 2, 83-93.

Wolters, E. A. (2014). Attitude-behavior consistency in household water consumption. The Social Science Journal, 51(3),

455-463. DOl: https://DOl.org/10.1016/i.soscii.2013.10.003

Wood, L. (2006). Dimensions of brand purchasing behaviour: consumers in the 18-24 age group. Journal of Consumer Behaviour, 4(1), 9-24. DOI: $10.1002 / \mathrm{cb} .154$

Yoo, B., \& Donthu, N. (2002). Testing cross-culture invariance of the brand equity creation process (Vol. 11)

Yoo, B., Donthu, N., \& Lee, S. (2000). An examination of selected marketing mix elements and brand equity. Journal of the Academy of Marketing Science, 28(2), 195. DOI: 10.1177/0092070300282002

Zeithaml, V. A., Berry, L. L., \& Parasuraman, A. (1996). The Behavioral Consequences of Service Quality. Journal of Marketing, 60(2), 31-46. DOI: 10.2307/1251929 
F. Zeng, M. Y. Bhutto, Y. A. Soomro. Chinese Smartphone Brands: Gender, Consumers Behavioural and Attitudinal Loyalty

Zhang, S., \& Schmitt, B. H. (2001). Creating Local Brands in Multilingual International Markets. Journal of Marketing Research, 38(3), 313-325. DOI: 10.1509/jmkr.38.3.313.18869

Zuhroh, D. H., Rofiaty and Djumahir. (2014). The Role of Brand Personality Congruity (BPC) on Brand Loyalty Mediated by Customer Value and Brand Trust (Study on Blackberry Smartphone Users). European Journal of Business and Management, Vol.6, No.21.

Ф'юе Зене, Уханський університет (Китай);

Мухаммед Ясеен Бхутто, Уханський університет (Китай);

Ясір Алі Соомро, Університет короля Абдул-Азіза (Саудівська Аравія).

Бренд китайських смартфонів: гендерний фактор, поведінка та лояльність споживачів

У статті проаналізовано взаємозв'язок між іміджом, популярністю, рівнем задоволення, довірою та лояльністю молоді до бренду китайських смартфонів. Крім того, у роботі авторами проаналізовано вплив гендерного фрактору на популярність бренду китайських смартфонів. При цьому аналіз наукової літератури з означеної тематики дослідження дозволив зробити висновок, що лише декілька раніше проведених досліджень стосуються теми брендів китайських смартфонів, а також поведінки та лояльності молоді до бренду китайських смартфонів. Таким чином, авторами зазначено, що дане дослідження сприяє розвитку теорії оцінки бренду. У статті розелянуто гендерні відмінності у сприйнятті бренду китайських смарторонів. Підгрунтям дослідження стали результати анкетування 188 студентів денної форми навчання приватного університету м. Ухань, Китай. При цьому аналіз даних здійснено на основі методу часткових найменших квадратів моделювання структурних рівнянь (PLS-SEM). Отримані результати дослідження вказують на суттєвий взаємозв'язок між іміджом та довірою до бренду, задоволенням брендом та довірою до нього, довірою до бренду та поведінкою і лояльністю. Авторами встановлено, що довіра до бренду є посередником у взаємозв'язку між іміджом, поведінкою і лояльністю споживачів, а також задоволенням брендом. Отримані результати дослідження дозволили виявити вплив іміджу на довіру до бренду з урахуванням гендерного фрактору. Так, визначено, що імідж та довіра до бренду є визначальними фракторами для чоловіків, на відмінну від жінок. Авторами встановлено, що влив задоволення брендом на довіру до нього є більш суттєвим для жінок, ніж для чоловіків. Таким чином, на основі отриманих результатів дослідження автори дійшли висновку, що китайські компанії повинні створювати довіру до бренду серед молоді за допомогою врахування їх стурбованості продуктом, оскільки імідж та задоволення брендом відіграють вагому роль у створенні лояльності до бренду. В результаті авторами визначено нові підходи до оцінки лояльності бренду, а також окреслено напрями для подальщих досліджень.

Ключові слова: імідж, бренд, задоволення брендом, довіра до бренду, поведінка, лояльність, гендерна рівність.

Manuscript received: 12.02.2019.

(C) The author(s) 2019. This article is published with open access at Sumy State University. 